\title{
The Institutional Power of Western European Parliaments: A Multidimensional Analysis
}

\author{
ULRICH SIEBERER
}

Parliaments are more than legislative bodies. However, we lack an adequate understanding of the theoretical relationship between different facets of parliamentary activity or 'parliamentary functions'. Relying on the principal agent framework, this article argues theoretically that parliamentary power is a multidimensional concept comprising three distinct mechanisms to ensure policy outputs in line with the collective preferences of parliaments: direct influence on policymaking, the ex ante selection of external officeholders, and the ex post control of the cabinet. These mechanisms mirror the classic legislative, electoral, and control functions of parliaments. Empirically, the paper uses factor analysis of newly developed indicators for electoral powers and established measures of legislative and control resources to show that the institutional powers of 15 Western European parliaments comprise four distinct dimensions. These dimensions match the three theoretically derived mechanisms with committee power as an additional factor. Locating the 15 parliaments in this multidimensional space of parliamentary powers demonstrates that classifications based solely on lawmaking lead to biased assessments of parliamentary strength and weakness. Instead, the paper provides a more nuanced picture of the ways in which Western European parliaments can influence policymaking under the conditions of delegation.

Can parliaments independently influence policy outputs in parliamentary systems that are characterised by strong political parties and substantial delegation of decision-making to the cabinet? If the answer is yes, by what means can they exercise such influence and how do they differ in their ability to do so? In recent years, a number of arguments have been advanced as to why parliaments are consequential even though they have little in common with an autonomous legislative body (Döring 1995a; Kim and Loewenberg 2005; Martin and Vanberg 2004; Strøm 1990). One key argument states that parliaments cannot be reduced to lawmaking but derive their power as much from the selection of external officeholders and control powers vis-à-vis the

Correspondence Address: ulrich.sieberer@uni konstanz.de 
cabinet as from legislative activity. Since the mid-nineteenth century, scholars have routinely mentioned such parliamentary functions in addition to lawmaking (Bagehot 1963 [1867]; Gallagher et al. 2006; Loewenberg and Patterson 1979; Norton 1990; 1998; Packenham 1990 [1970]). However, the literature is largely silent on the question of how parliamentary powers with regard to different functions are related theoretically and empirically. In addition, we have little systematic knowledge of the institutional powers of European parliaments in areas other than lawmaking. Consequently, comparative assessments of parliamentary power are based exclusively on this aspect, even when the relevance of other facets of parliamentary activity is acknowledged theoretically (Blondel 1973; Mezey 1979; Polsby 1975).

This paper argues that parliaments can have independent effects on policy outputs and identifies three theoretically and empirically distinct mechanisms for this influence. Drawing on the principal-agent framework, it provides a theoretical rationale for a multidimensional concept of institutional parliamentary power that reconciles conceptions of parliaments as multifunctional bodies with rational choice institutionalist scholarship on parliaments. I argue that established parliamentary functions can be understood as distinct mechanisms for reaching the common goal of ensuring policy outputs in line with the collective preferences of parliament under the conditions of delegation. Theoretically, I derive direct influence on policymaking (in classical terminology the lawmaking function), ex ante selection of external officeholders (elective function), and ex post control of the cabinet (control function) as means to this end. I argue that these mechanisms should constitute empirically independent dimensions of parliamentary powers and thus challenge the dominant conceptualisation of parliamentary power as a unidimensional phenomenon. As a second contribution, I develop new measures for the electoral powers of parliaments as a theoretically central but empirically largely neglected facet of parliamentary power. Third, I use factor analysis to show that the institutional power of 15 Western European parliaments is indeed multidimensional, with three distinct factors mirroring the theoretically derived mechanisms. Locating parliaments in this three-dimensional space reveals several deviations from conventional wisdom and demonstrates that classifications based solely on lawmaking powers lead to a biased assessment of parliamentary strength and weakness.

The next section provides arguments why the parliamentary arena can have independent effects on policy outputs in parliamentary systems and introduces principal-agent theory as a useful framework for comparative legislative studies. On this basis, I identify three analytically distinct mechanisms for limiting agency loss that mirror classic parliamentary functions and derive hypotheses about the dimensionality of institutional parliamentary power. The third section introduces the data used to test these hypotheses and develops new measures of the electoral competencies of parliaments. I present the empirical results supporting my hypotheses in the 
fourth section and conclude by summarising the argument and discussing perspectives for future research.

\section{Parliamentary Power as a Multidimensional Concept}

\section{The Relevance of Parliaments and the Principal-Agent Framework}

The dominance of political parties in parliamentary democracies leads to the question of whether parliaments have any independent effects on policy outputs at all. One strand in the literature denies such an effect by assuming parties to be perfectly unitary actors across different institutional arenas. For example, George Tsebelis (2002) only counts cabinet parties as veto players and assumes that co-partisans in cabinet and parliament have identical preferences. However, there are various arguments why the parliamentary arena remains important. First, parliament can be a decisive stage for negotiation and legislative coalition formation under minority cabinets giving parliamentary actors from non-governing parties direct influence on policy (Strøm 1990). Second, parliamentary institutions can help cabinet parties counteract dangers from delegation by giving them a mutual veto against bills drafted by individual ministers (Martin and Vanberg 2004) and by facilitating the scrutiny of ministers through committees (Kim and Loewenberg 2005). Both arguments postulate an indirect influence of parliamentary actors on policy outputs even if the unitary actor assumption is upheld. Finally, once we relax this assumption, intraparty minorities, especially from governing parties, can affect policy outputs both directly via parliamentary voting and indirectly via anticipation by the cabinet.

These arguments not only support the view that parliaments can be influential in the context of parliamentary democracies but also highlight three requirements for a theoretical framework to study this influence. First, it must start from the dualism between parliamentary majority and cabinet on the one side and parliamentary opposition on the other side instead of treating parliament as a corporate actor opposed to the cabinet (King 1976). Second, political parties must be integrated as mechanisms that can align actor preferences across institutional arenas. In fact, political parties are the central actors in parliamentary democracies. Third, the extent to which political parties are unitary actors should be determined empirically rather than by assumption (Carey 2007; Sieberer 2006a).

These requirements are met nicely by the principal-agent (PA) framework that has recently received increased attention in various fields of comparative politics (e.g. Braun and Gilardi 2006; Strøm 2000; Strøm et al. 2003; Thatcher and Stone Sweet 2002). First, the framework can explain the close ties between the parliamentary majority and the cabinet as well as the former's voluntary delegation to the latter as a consequence of the confidence relationship between parliament and cabinet. At the same 
time, it theoretically allows for preference divergence between the parliamentary majority and the cabinet. Second, the central role of political parties can be integrated systematically (Müller 2000). Third, the PA approach conceptualises the strength of parties as a variable central to explaining the (lack of) agency loss instead of assuming perfectly unitary parties as a constant ensuring successful delegation.

From a PA perspective, parliamentary democracies consist of a singular and indirect chain of delegation including four steps (Strøm 2000, 2003): (1) the people as ultimate principal delegates to members of parliament; (2) the parliamentary majority delegates to the prime minister and his or her cabinet; (3) prime minister and cabinet delegate to individual ministers; and (4) individual ministers delegate to bureaucrats. A chain of responsibility runs in the reverse direction, making each agent accountable to his or her direct principal. This paper focuses on the delegation from parliament as principal to the prime minister and the cabinet as agents. This delegation can be beneficial for parliamentary actors because it increases the capacity for action through a division of labour and the use of specific qualifications in the executive branch. However, cabinet decisions can deviate from what the parliamentary majority would do, creating the danger of agency loss. Thus, the challenge consists in allowing delegation and at the same time limiting its dangers. This challenge is particularly urgent because cabinets have become the most important site of policymaking in modern parliamentary democracies.

I argue that we can understand parliamentary institutions as answers to this challenge. The next section shows that many functions of parliaments identified in the literature directly relate to different mechanisms for reducing agency loss and for ensuring policy outputs in line with the collective preference of parliament under the conditions of delegation.

\section{Parliaments as Multifunctional Bodies: A Principal-Agent Perspective}

Starting from Walter Bagehot's (1963 [1867]) famous catalogue, parliaments are routinely ascribed multiple functions. Bagehot distinguishes the 'elective function' of selecting and maintaining the cabinet, ${ }^{1}$ the 'expressive', 'teaching' and 'informing' functions and finally lawmaking as a relatively unimportant task. More recent catalogues make minor changes and adapt terminology to structural-functionalist parlance, but the general idea remains the same (Loewenberg and Patterson 1979; Norton 1990, 1998; Packenham 1990 [1970]). These studies indicate that parliaments, especially in parliamentary democracies, are much more than legislatures (Laver 2006). Nonetheless, they leave central questions unanswered or even unasked. Most importantly, they neglect the question of how different functions relate to each other theoretically and empirically within individual parliaments. ${ }^{2}$ Does a powerful position of a parliament with regard to one function also imply strength in other areas as the undifferentiated 
characterisation of specific parliaments as 'strong' or 'weak' suggests? Or should we observe a mixture of strength and weakness depending on the functions we look at?

Before turning to this question, I have to explain how 'power' is conceptualised in this paper. In line with the rational choice institutionalist framework I assume that the power of parliamentary actors rests on institutional resources which allow them to exercise influence over the cabinet and other external actors. Institutional resources privilege some actors over others by giving them the right to perform certain actions and enhancing their influence over collective decisions. Institutional rules provide structural incentives for actors to behave in certain ways but they do not determine outcomes. The effect of institutions is thus similar to the concept of power itself in that they are 'dispositional' (Dowding 1996: 3-4). They capture potentials for action which can but do not have to be used by actors. ${ }^{3}$ Ultimate decisions depend both on these incentives and on actor preferences. Accordingly, individual outcomes can be explained only by the interaction of the (relatively) stable institutional environment and the more flexible actor constellation which derives from variables such as individual parties' preferences and internal unity, the competitive dynamics of the party system, and the cabinet format. Nonetheless, the institutional powers analysed in this paper are worth studying in their own right as they form a central piece of the larger puzzle of how parliaments can matter for policy outputs in parliamentary democracies.

More specifically, the institutional powers of parliamentary actors can be understood as mechanisms to ensure policy outputs in line with the collective preference of parliament under the conditions of delegation. Given the central role of cabinets as policymakers, these mechanisms are mainly designed to give parliamentary actors direct or indirect influence on cabinet decisions. Many (though not all) established parliamentary functions represent mechanisms for reaching this goal. ${ }^{4}$ Re-conceptualising parliamentary functions as bundles of institutional powers allows us to study them within the rational choice institutionalist framework which solves many of the problems that plague the structural-functionalist paradigm in which most literature on parliamentary functions is rooted (Gamm and Huber 2002).

From a PA perspective, we can distinguish three distinct mechanisms for assuring policy outputs in line with parliamentary preferences: (1) direct influence on policymaking; (2) the ex ante selection of agents; and (3) their ex post control. First, parliamentary actors can forgo delegation altogether. This makes agency loss logically impossible but also abandons the potential benefits of delegation. The decision to delegate can be understood as a rational trade-off between the expected gains and losses from delegation (Epstein and O'Halloran 1999). Parliament forgoing delegation and making relevant policy decisions itself corresponds to the traditional legislative function. 
If, on the other hand, an actor decides to delegate power, she can limit the danger of agency loss in two ways (Kiewiet and McCubbins 1991; Strøm 2003). First, the principal can influence the expected behaviour of agents ex ante by selecting candidates who share the same preferences. This focus on screening and selection addresses the problem of adverse selection and, if successful, leads to the selection of agents who act in the interest of the principal by following their own preferences. This ex ante influence manifests itself institutionally in the electoral powers of parliaments - the elective function. The most important electoral powers relate to choosing the cabinet, but parliaments also elect other external officeholders such as heads of states, constitutional judges, officeholders in audit institutions, and ombudsmen who can either directly influence policy outputs or help parliament decrease informational asymmetries vis-à-vis the cabinet.

Second, principals can monitor agents' behaviour ex post to detect and if necessary sanction actions against the principal's interests. Monitoring can be achieved either by direct oversight ('policy patrol') or by relying on information supplied by interested third parties ('fire alarms') (McCubbins and Schwartz 1984). This strategy addresses the problem of moral hazard arising from informational asymmetries between principal and agent. Decreasing such asymmetries induces agent behaviour in line with the principal's wishes even in the case of preference divergence. In the relationship between parliament and cabinet, this ex post strategy captures the classic function of parliamentary control of the executive.

These three mechanisms are to some extent substitutable. Most obviously, the two mechanisms to limit agency loss are less important if parliament retains significant direct influence over policymaking. Second, a strong position in the selection of agents makes ex post control less urgent because agents should usually act in the principal's interest due to concurrent preferences. On the other hand, strong ex post control powers can compensate for preference divergence between principal and agent.

However, the mechanisms are not perfect substitutes. First, even a parliament with strong policymaking powers cannot completely do without delegation, given the amount and complexity of regulation in modern democracies. Thus all parliaments need some means to influence the behaviour of agents either ex ante or ex post. Second, ex ante selection and ex post control focus on different forms of agency loss. Ex ante selection primarily addresses adverse selection but cannot solve moral hazard problems arising once the agent assumes office. Ex post control can deal with moral hazard and to some extent ameliorate the negative consequences of adverse selection (at least if they result from policy divergence rather than sheer incompetence), but it entails high costs decreasing the overall value of delegation. Thus, control powers alone are unlikely to lead to satisfactory results if the preference divergence between principal and agent is large.

What relationship should we then expect between parliamentary powers with regard to the three mechanisms? Given the possibilities for substitution, 
parliaments should not be consistently strong or weak with regard to all three mechanisms, i.e. institutional powers relating to different parliamentary functions should not be strongly positively correlated. On the other hand, focusing solely on one mechanism is problematic given the need for delegation and the different problems addressed by ex ante and ex post control. Thus, institutional implementation of the different mechanisms should not be strongly negatively correlated either. Instead, the theoretical multidimensionality of parliamentary power should also hold empirically. Thus, different parliaments should display varying combinations of strength and weakness on the different dimensions. This leads to two hypotheses, both of which challenge the prevailing view of parliamentary power as a unidimensional concept:

H1: Institutional powers of parliaments cluster empirically in at least three distinct dimensions.

H2: These dimensions correspond to parliamentary powers with regard to (1) direct influence on policymaking, (2) the ex ante selection of external officeholders, and (3) the ex post control of the cabinet.

\section{Cases, Variables, and the Electoral Powers of Parliament \\ Case Selection}

We need a broad array of measures of the institutional powers of parliaments to test the hypotheses on their clustering with regard to the three theoretically derived mechanisms of parliamentary influence on policy outputs. A number of useful indicators are available in the literature. Unfortunately, the availability of this data limits the countries that can be covered to 15 parliamentary democracies in Western Europe. ${ }^{5}$ However, this sample covers a sufficiently large portion of stable parliamentary democracies to draw an informative picture of parliamentary power and furthermore ensures compatibility with existing comparative literature (e.g. Döring 1995a; Strøm et al. 2003; Tsebelis 2002). Throughout the paper, I analyse only the lower chambers of bicameral parliaments to which the cabinet is accountable and which can thus be understood as the latter's principal. ${ }^{6}$ In the next subsection I present the variables used to measure parliamentary powers with regard to lawmaking and government control.

\section{Measuring Direct Influence on Policymaking and ex post Control}

I capture the ability of parliaments to influence policymaking directly with variables on legislative agenda-setting, the lawmaking powers of parliamentary committees, and parliamentary involvement in the budgetary process. Agenda-setting powers comprise various institutional prerogatives 
that allow cabinets to dominate the legislative process and thus decrease the direct influence of parliamentary actors on policymaking (Döring 1995b; Rasch and Tsebelis 2011; Sieberer 2006b). I use variables on the cabinet's ability to control the plenary agenda, its control of the agenda in parliamentary committees, and its ability to curtail debates (all taken from Döring 1995b). Second, strong committees are generally considered the most effective way for parliamentary actors to influence legislative outputs (Mattson and Strøm 1995; Strøm 1990). I capture committee strength in the legislative process through their rights to redraft and amend bills (Döring 1995b) and to initiate legislation (Mattson and Strøm 1995). Finally, parliamentary actors can influence policy outputs via the budgetary process because almost all government programmes depend on monetary resources. ${ }^{7}$ Parliamentary involvement in this process is measured with a composite index developed by Wehner (2006).

Parliamentary powers to control the cabinet are measured in three ways. First, I analyse control powers of parliamentary committees that should be more effective controllers than the plenary due to specialisation (Kim and Loewenberg 2005; Mattson and Strøm 1995). I use two variables measuring the rights of committees to compel witnesses and to demand documents (Mattson and Strøm 1995). Both powers allow control of the cabinet through attaining information on cabinet actions and reducing informational asymmetries. Second, parliamentary actors can use questions to extract information on executive actions. Relying on Wiberg's (1995) distinction of nine forms of parliamentary questions, I construct a simple additive index of the forms of questioning available to parliamentary actors. Third, I use two composite indices of parliamentary control structures and control rights developed by Schnapp and Harfst (2005) that include among other variables information on the structure and size of parliamentary committees and the existence of external parliamentary support bodies such as audit institutions and ombudsmen. Detailed information on the operationalisation of all variables taken from the literature is provided in the Appendix. ${ }^{8}$

\section{Measuring Electoral Powers of Parliaments}

So far, there is almost no comparative data on the electoral powers of European parliaments. Two studies investigate the selection of intraparliamentary officeholders such as presidents of parliaments, members of steering committees or committee chairs (Carroll et al. 2006; Jenny and Müller 1995). These electoral powers, however, cannot ameliorate the problems arising from delegation beyond parliament. With a narrower focus on government formation, the existence of an investiture vote has been identified as an important variable, especially for the likelihood of minority cabinets (Bergman 1993) and cabinet durability (King et al. 1990; Saalfeld 2008). I use a dummy variable 'positive parliamentarism' coded 1 if the prime minister or the cabinet have to win a formal vote in parliament before 
or right after taking office and 0 otherwise. Closely related to the election of the cabinet is the power of parliaments to force the cabinet out of office through a vote of no confidence. However, this power is by definition available to all parliaments in parliamentary systems of government (albeit with differences in detail) and thus is of limited help in differentiating among them. Therefore I do not include the power to displace the cabinet in the analysis. $^{9}$

Systematic data on electoral powers of parliaments with regard to other external officeholders is completely absent. To fill this gap, I develop two indices measuring the existence and institutional form of such electoral powers. Again, it should be pointed out that the institutional rules only provide incentives for certain kinds of behaviour and outcomes. Even though their actual effects depend on the time-specific actor constellation (both between and within parties), the institutional approach is valuable because it captures relatively stable characteristics of elections in parliament.

The 'Parliamentary Freedom of Choice Index' (PFCI) captures the autonomy of parliament in implementing its collective preference without outside interference. The 'Incentives to Constrain Index' (ICI) captures the institutionally mediated likelihood that officeholders elected by parliament will hold preferences diverging from those of the cabinet. I use these indices to measure the electoral powers of the 15 Western European parliaments with regard to five offices (prime ministers and cabinets, heads of state, constitutional judges, heads of audit institutions and ombudsmen). These measures are valuable beyond this paper as the first systematic account of a broader range of electoral powers of European parliaments.

Institutionally, the freedom of parliament to implement its collective preference depends on the admissible number of candidates and the nominating actors. In the 'approval model', only one candidate may be nominated which can enable the nominator as agenda setter to reach outcomes distant from the collective ideal point of parliament (in a onedimensional model the median deputy) as long as the candidate is preferred by a majority over the status quo (Romer and Rosenthal 1978). ${ }^{10}$ In the 'competitive elections model', on the other hand, competition among candidates is allowed and the median voter logic should lead to the election of a candidate located at or near the collective ideal point of parliament (Black 1987 [1958]; Downs 1957). Some deviations towards the nominating actor are possible if nominations are limited to one or few actors (e.g. to parties of a certain size), or if parties suffer reputational costs from nominating candidates far from their ideal points (Downs 1957: 122).

I distinguish between three nominators: (1) parliamentary actors; (2) cabinet actors; and (3) third parties outside the parliamentary chain of delegation, most frequently the head of state. ${ }^{11}$ Parliamentary freedom of choice is largest if parliamentary actors can nominate candidates themselves. It is smaller for nominations by cabinet actors, especially when it comes to electing officeholders charged with controlling cabinet actions. In conflicts 
with the parliamentary majority over such an election, the cabinet is likely to prevail as it can link the election to policy decisions or even an explicit or implicit vote of confidence. The constraining effect of third party nominations on parliament is hard to assess because there is no systematic information on preference deviations between third parties and parliament. However, third parties lack the cabinet's institutional and political means for making the parliamentary majority follow their wishes. Thus, I expect third party nominations to be less constraining on parliament than cabinet nominations.

Combining the two variables leads to six models of parliamentary elections (Table 1). To capture the joint effects of both variables, I combine them in an index. Unfortunately - a problem frequently encountered in comparative politics - theoretical arguments lead to ordinal predictions but provide little guidance on how much the freedom of choice increases in metric terms. Therefore, index construction requires some potentially controversial assumptions. I justify all assumptions theoretically and show that plausible alternatives lead to very similar empirical results (notes 12 to 15). First, candidate nomination is assumed to be the more important dimension because the agenda-setter advantage can be relevant even in the competitive elections model if nominations are limited to the cabinet and third parties. Therefore, the two models with parliamentary nomination receive the highest scores followed by the models with third party nomination and the ones with cabinet nomination. The pairs of models with equal nominators are ordered by the admissible number of candidates. ${ }^{12}$ Second, I assume equal distances between the individual models which is a customary fall-back option in the absence of strong theoretical reasons for unequal distances. Third, the freedom of a parliament is obviously zero if it is not involved in the selection process. Assigning scores between 0 and 1 thus leads to the PFCI values in Table 1.

Measuring the freedom of parliament as a collective actor is not sufficient under the conditions of parliamentary democracies, because the effects of an

TABLE 1

THE FREEDOM OF PARLIAMENT TO IMPLEMENT ITS COLLECTIVE PREFERENCE IN ELECTIONS: THE PARLIAMENTARY FREEDOM OF CHOICE INDEX (PFCI)

\begin{tabular}{lcccc}
\hline & \multicolumn{3}{c}{ Nominating actor } \\
\cline { 3 - 5 } & & Parliament & Third party & Cabinet \\
\hline Institutionally admissible & 1 & AM1 & AM2 & AM3 \\
number of candidates & & $(0.83)$ & $(0.50)$ & $(0.17)$ \\
& $>1$ & CEM1 & CEM2 & CEM3 \\
& & $(1.0)$ & $(0.67)$ & $(0.33)$ \\
\hline
\end{tabular}

Note: AM approval model; CEM competitive elections model.

Values of the Parliamentary Freedom of Choice Index in parentheses.

PFCI 0 if the officeholder is selected without parliamentary involvement. 
election critically depend on whose preferences within parliament are decisive. In particular, the degree to which electoral powers ensure independent parliamentary influence hinges on whether parliamentary actors with preferences deviating from those of the cabinet can affect the outcome and thus elect officeholders with preferences different from those of the cabinet. Two such actors come to mind: opposition parties and minorities within governing parties. While their precise impact in individual elections cannot be assessed without information on the time-specific distribution of preferences in parliament, institutional variables make such influence more or less likely and can thus serve as proxy variables. The influence of opposition parties institutionally depends on the majority requirement and increases as we move from simple majority via absolute majority of all members of parliament to qualified majorities. While even minority governments can often prevail under simple majority by benefiting from abstentions and splits in the opposition camp, absolute majority requires the explicit support of opposition parties in situations of minority government. Under qualified majority, even majority cabinets usually need votes from opposition parties to get a candidate elected. The influence of intra-party minorities depends on the ability of the party leadership to observe and sanction deviations from the party line. This monitoring capacity is reduced and the influence of intra-party minorities thus increases if voting is secret as compared to open or semi-open (Saalfeld 1995). However, the constraining effect of intra-party minorities should be less than that of opposition parties because co-partisans share common interests beyond a potentially controversial election.

Combining the variables majority requirement and voting method with the PFCI leads to the ICI, which captures the institutionally mediated likelihood that elections in parliament lead to the selection of external officeholders with preferences deviating from those of the cabinet. The majority requirement is coded $1,1.5$, and 2 for simple, absolute, and qualified majorities, and the PFCI scores are multiplied with these factors. ${ }^{13}$ The multiplicative link is based on the argument that the individual effects reinforce each other, i.e. the constraint on the cabinet increases disproportionately if parliaments are both free in implementing their preference and opposition parties influence the outcome. ${ }^{14}$ Furthermore, I add a score of 0.33 if an election is secret to capture the additional constraint through minorities within governing parties. The value amounts to only one-third of the total range of the PFCI and thus reflects the theoretically lower importance of the voting method. ${ }^{15}$ Due to the additive link, this variable is relatively more important when the other elements of the index are low. This reflects the idea that governing parties are most concerned with making their fellow partisans toe the line when they do not have to compromise with opposition parties. In contrast, some intraparty dissent may (have to be) tolerated if such parties are necessary for the electoral coalition. The final Incentives to Constrain Index has a theoretical range from 0 (if parliament is 
not involved in the selection at all) to 2.33 (if parliament chooses between several candidates nominated by parliamentary actors in a secret vote requiring a qualified majority).

Using these indices, I measure the electoral powers of parliaments with regard to five offices: the prime minister and/or the cabinet; the head of state; constitutional judges; heads of audit institutions; and ombudsmen. ${ }^{16}$ This selection of offices includes both the cabinet as the central agent of parliament and external officeholders that can constrain the cabinet's freedom of action as veto players (constitutional judges and some heads of state) or as 'powerful players' (Strøm 2003) (heads of audit institutions, ombudsmen and heads of state without veto power). Powerful players influence policy outputs indirectly by providing information and creating public attention which can in turn affect the behaviour of actors with veto power. The institutional selection rules are coded from the relevant legal sources, information on the websites of the respective parliaments and external offices, and personal communication with the parliaments and country experts (see Sieberer 2010 for details on the data sources). I use the rules on the last ballot because actors should evaluate the strategic situation from this endpoint. When parliaments elect only a fraction of officeholders in a collective body (which is often the case for constitutional courts), I weight the indices with this percentage. When officeholders are elected by mixed assemblies including members of parliament and for example members of second chambers or sub-national assemblies, I weight the index values with the proportion of members of parliament in the mixed assembly.

This procedure results in up to five measurements per country. ${ }^{17}$ These values are added and the sum is divided by the number of offices existing in the country leading to one overall score for each parliament's electoral powers. ${ }^{18}$ Due to the different political relevance of the external offices one might prefer an aggregation rule that gives more weight to more important offices. However, as such rules empirically lead to very similar results I use the more transparent unweighted scores. ${ }^{19}$ Table 2 lists the PFCI and ICI scores for the 15 Western European parliaments covered in this paper, providing the first systematic measurement of their electoral powers.

\section{The Dimensionality of Institutional Parliamentary Power in Western Europe}

With the 14 indicators discussed in the previous section, we can turn to testing the hypotheses about the dimensionality of parliamentary power. Table 3 contains basic descriptive statistics for all variables. Note that the parliaments display considerable variation on all indicators as measured by the standard deviation and cover the entire theoretical range of many of them. Thus, Western European parliaments differ in their institutional powers with regard to various facets of parliamentary activity. However, 
TABLE 2

ELECTORAL POWERS OF 15 WESTERN EUROPEAN PARLIAMENTS

\begin{tabular}{lcc}
\hline & $\begin{array}{c}\text { Parliamentary Freedom } \\
\text { of Choice Index (PFCI) }\end{array}$ & $\begin{array}{c}\text { Incentives to Constrain } \\
\text { Index (ICI) }\end{array}$ \\
\hline Austria & 0.37 & 0.52 \\
Belgium & 0.60 & 0.91 \\
Denmark & 0.41 & 0.41 \\
Finland & 0.58 & 0.75 \\
France & 0 & 0 \\
Germany & 0.54 & 1.06 \\
Greece & 0.58 & 1.04 \\
Ireland & 0.62 & 0.62 \\
Italy & 0.34 & 0.54 \\
Netherlands & 0.50 & 0.67 \\
Norway & 0.41 & 0.41 \\
Portugal & 0.45 & 0.92 \\
Spain & 0.47 & 0.95 \\
Sweden & 0.71 & 0.87 \\
United Kingdom & 0.04 & 0.04 \\
\hline
\end{tabular}

Note: Index construction: see text.

parliamentary power could still be one-dimensional if all variables were highly correlated.

I employ factor analysis using the principal factors method and subsequent varimax rotation to detect underlying dimensions of parliamentary power. ${ }^{20}$ The number of extracted factors directly tests the claim that parliamentary power is an empirically multidimensional phenomenon with at least three separate dimensions (H1). Patterns in the factor loadings of the individual variables allow a substantive interpretation of the factors and an assessment of $\mathrm{H} 2$ according to which the dimensions of parliamentary power should reflect the three theoretical mechanisms to ensure policy outputs in line with the collective preferences of parliament.

Based on the Kaiser-Guttman criterion, I extract four factors with eigenvalues greater than 1 . As these eigenvalues may heavily depend on individual cases and their statistical significance cannot be estimated parametrically given the small number of observations, I establish confidence intervals via bootstrap simulations. The lower end of the 95 per cent interval exceeds 1 for the eigenvalues of all four factors. ${ }^{21}$ The factors capture 81.3 per cent of the total variance and thus adequately represent the data. Table 4 shows the factor loadings and uniqueness values (i.e. the fraction of variance in the variable not captured by the factors) of the variables, the eigenvalues of the factors, and the proportion of the total variance captured by each factor.

The empirical analysis provides strong support for both hypotheses. The four factors establish the multidimensional nature of parliamentary powers expected in H1. Furthermore, three of the factors (factors I-III) clearly correspond to the theoretically derived dimensions and thus confirm $\mathrm{H} 2{ }^{22}$ The first factor captures the ability of parliamentary actors to directly 
TABLE 3

DATA SOURCES AND DESCRIPTIVE STATISTICS

\begin{tabular}{|c|c|c|c|}
\hline & Source & $\begin{array}{l}\text { Mean } \\
\text { (SD) }\end{array}$ & $\begin{array}{l}\text { Empirical range } \\
\text { (Theoretical range) }\end{array}$ \\
\hline $\begin{array}{l}\text { Determine plenary } \\
\text { agenda }\end{array}$ & Doring 1995b & $\begin{array}{c}3.80 \\
(1.74)\end{array}$ & $\left.\begin{array}{rl}1 & 7 \\
(1 & 7\end{array}\right)$ \\
\hline $\begin{array}{l}\text { Control committee } \\
\text { timetable }\end{array}$ & Doring 1995b & $\begin{array}{c}2.33 \\
(1.05)\end{array}$ & $\left.\begin{array}{ll}1 & 4 \\
(1 & 4\end{array}\right)$ \\
\hline Curtailing of debate & Doring 1995b & $\begin{array}{l}1.93 \\
(0.70)\end{array}$ & $\left.\begin{array}{ll}1 & 3 \\
(1 & 3\end{array}\right)$ \\
\hline $\begin{array}{l}\text { Committees: Rewrite } \\
\text { government bills }\end{array}$ & Doring $1995 b$ & $\begin{array}{c}2.73 \\
(1.39)\end{array}$ & $\left.\begin{array}{ll}1 & 4 \\
(1 & 4\end{array}\right)$ \\
\hline $\begin{array}{l}\text { Committees: } \\
\text { Initiation of bills }\end{array}$ & Mattson and Strøm 1995 & $\begin{array}{l}1.87 \\
(0.74)\end{array}$ & $\left.\begin{array}{ll}1 & 3 \\
(1 & 3\end{array}\right)$ \\
\hline $\begin{array}{l}\text { Legislative budget } \\
\text { institutions }\end{array}$ & Wehner 2006 & $\begin{array}{l}41.85 \\
(16.65)\end{array}$ & $\begin{array}{l}16.7065 .30 \\
\left(\begin{array}{ll}0 & 100)\end{array}\right)\end{array}$ \\
\hline $\begin{array}{l}\text { Committees: Compel } \\
\text { witnesses }\end{array}$ & Mattson and Strøm 1995 & $\begin{array}{c}0.20 \\
(0.41)\end{array}$ & $\begin{array}{l}0 ; 1^{*} \\
(0 ; 1)\end{array}$ \\
\hline $\begin{array}{l}\text { Committees: } \\
\text { Demand } \\
\text { documents }\end{array}$ & Mattson and Strøm 1995 & $\begin{array}{c}0.40 \\
(0.51)\end{array}$ & $\begin{array}{l}0 ; 1^{*} \\
(0 ; 1)\end{array}$ \\
\hline $\begin{array}{l}\text { Parliamentary } \\
\text { questions }\end{array}$ & $\begin{array}{l}\text { Own calculations based on } \\
\text { Wiberg } 1995\end{array}$ & $\begin{array}{c}4.73 \\
(1.79)\end{array}$ & $\left.\begin{array}{ll}2 & 8 \\
(0 & 9\end{array}\right)$ \\
\hline Control structures** & Schnapp and Harfst 2005 & $\begin{array}{c}8.73 \\
(3.16)\end{array}$ & $\begin{array}{l}13.90 \text { to } 3.30 \\
\text { ( } 21 \text { to } 1)\end{array}$ \\
\hline Control rights** & Schnapp and Harfst 2005 & $\begin{array}{l}10.70 \\
(2.29)\end{array}$ & $\begin{array}{l}16.10 \text { to } 7.00 \\
\text { ( } 21 \text { to } 1)\end{array}$ \\
\hline $\begin{array}{l}\text { Positive } \\
\text { parliamentarism }\end{array}$ & $\begin{array}{l}\text { Own calculations based on } \\
\text { rules in } 2006\end{array}$ & $\begin{array}{c}0.47 \\
(0.52)\end{array}$ & $\begin{array}{l}0 ; 1^{*} \\
(0 ; 1)\end{array}$ \\
\hline $\begin{array}{l}\text { Parliamentary } \\
\text { freedom of choice }\end{array}$ & $\begin{array}{l}\text { Own calculations based on } \\
\text { rules in } 2006\end{array}$ & $\begin{array}{c}0.44 \\
(0.20)\end{array}$ & $\begin{array}{ll}0 & 0.71 \\
\left(\begin{array}{ll}0 & 1\end{array}\right)\end{array}$ \\
\hline $\begin{array}{l}\text { Incentives to } \\
\text { constrain }\end{array}$ & $\begin{array}{l}\text { Own calculations based on } \\
\text { rules in } 2006\end{array}$ & $\begin{array}{c}0.65 \\
(0.33)\end{array}$ & $\left.\begin{array}{cc}0 & 1.06 \\
(0 & 2.33\end{array}\right)$ \\
\hline
\end{tabular}

Note: For all variables, large values indicate a strong position of the parliament.

*Dummy variable.

**The variable was multiplied by 1 so that large values indicate strong parliaments.

influence policymaking via legislation. The second factor comprises electoral powers that enable parliaments to select officeholders with similar preferences. The third factor contains ex post control powers vis-à-vis the cabinet. Almost all variables strongly load on only one factor each; thus the factors capture clearly distinct dimensions of parliamentary powers. ${ }^{23}$

Somewhat surprisingly, I find a fourth factor that relates mainly to committee powers. Theoretically, the variables loading primarily on this factor should have been part of the factors on direct policy influence (rewrite authority and initiation of bills) and ex post control (demand documents and parliamentary questions). Note, however, that three of the four variables primarily loading on factor IV display rather high uniqueness values and thus do not fit as well into the factor solution as the other variables. Accordingly, the result should not be over-interpreted.

Let us nonetheless speculate about how we might explain the independence of this fourth factor. An explanation could build on the 
TABLE 4

THE DIMENSIONALITY OF PARLIAMENTARY POWER IN WESTERN EUROPE

\begin{tabular}{|c|c|c|c|c|c|}
\hline & $\begin{array}{c}\text { Factor I } \\
\text { (direct policy } \\
\text { influence) }\end{array}$ & $\begin{array}{l}\text { Factor II } \\
\text { (ex ante } \\
\text { selection) }\end{array}$ & $\begin{array}{l}\text { Factor III } \\
\text { (ex post } \\
\text { control) }\end{array}$ & $\begin{array}{l}\text { Factor IV } \\
\text { (committee } \\
\text { power) }\end{array}$ & Uniqueness \\
\hline Determine plenary agenda & 0.822 & 0.143 & 0.120 & 0.157 & 0.265 \\
\hline $\begin{array}{l}\text { Control committee } \\
\text { timetable }\end{array}$ & 0.769 & 0.004 & 0.119 & 0.177 & 0.363 \\
\hline Curtailing of debate & 0.882 & 0.233 & 0.015 & 0.173 & 0.138 \\
\hline $\begin{array}{l}\text { Legislative budget } \\
\text { institutions }\end{array}$ & 0.916 & 0.061 & 0.252 & 0.074 & 0.088 \\
\hline Positive parliamentarism & 0.425 & 0.768 & 0.011 & 0.234 & 0.174 \\
\hline $\begin{array}{l}\text { Parliamentary freedom of } \\
\text { choice }\end{array}$ & 0.367 & 0.840 & 0.003 & 0.088 & 0.152 \\
\hline Incentives to constrain & 0.219 & 0.890 & 0.058 & 0.056 & 0.154 \\
\hline Control structures & 0.561 & 0.267 & 0.686 & 0.065 & 0.140 \\
\hline Control rights & 0.141 & 0.116 & 0.838 & 0.103 & 0.255 \\
\hline $\begin{array}{l}\text { Committees: Compel } \\
\text { witnesses }\end{array}$ & 0.080 & 0.150 & 0.934 & 0.174 & 0.070 \\
\hline $\begin{array}{l}\text { Committees: Rewrite } \\
\text { government bills }\end{array}$ & 0.326 & 0.553 & 0.049 & 0.628 & 0.192 \\
\hline $\begin{array}{l}\text { Committees: Initiation of } \\
\text { bills }\end{array}$ & 0.307 & 0.389 & 0.025 & 0.631 & 0.355 \\
\hline $\begin{array}{l}\text { Committees: Demand } \\
\text { documents }\end{array}$ & 0.126 & 0.098 & 0.026 & 0.798 & 0.338 \\
\hline Parliamentary questions & 0.227 & 0.031 & 0.444 & 0.687 & 0.279 \\
\hline Eigenvalue of the factor & 5.026 & 2.484 & 2.096 & 1.434 & \\
\hline $\begin{array}{l}\% \text { variance attributed to } \\
\text { rotated factor }\end{array}$ & 0.284 & 0.202 & 0.172 & 0.155 & \\
\hline
\end{tabular}

Note: Extraction by the principal factors method with subsequent varimax rotation. Factors extracted according to Kaiser Guttman criterion. The eigenvalues of all four factors are statistically significant $>1$ according to bootstrap simulation. Cells contain factor loadings; highest value of each variable in bold.

N 15 .

argument that committees not only serve as agents of their parent chambers to increase the efficiency of parliamentary decision-making but also constitute an opportunity structure for parliamentarians to pursue particularistic goals. Committees may be composed of preference outliers and thus make choices different from those of the plenary (Shepsle 1979). Accordingly, the creation and institutional design of committees may be driven by distributive goals of groups of MPs that are independent of the needs of parliament as a collective actor. Parliamentary questions as the fourth variable loading on this factor can also be used for particularistic purposes by individual parliamentarians. Thus, factor IV may pick up the tension between individual and collective interests with regard to the distribution of power within parliaments. This path of explanation could be tested more systematically in future work on the institutional design of parliamentary committees.

How do individual parliaments score on the different dimensions of institutional power? Figure 1 locates the 15 Western European parliaments 
FIGURE 1

A THREE-DIMENSIONAL MAP OF INSTITUTIONAL PARLIAMENTARY POWER IN WESTERN EUROPE

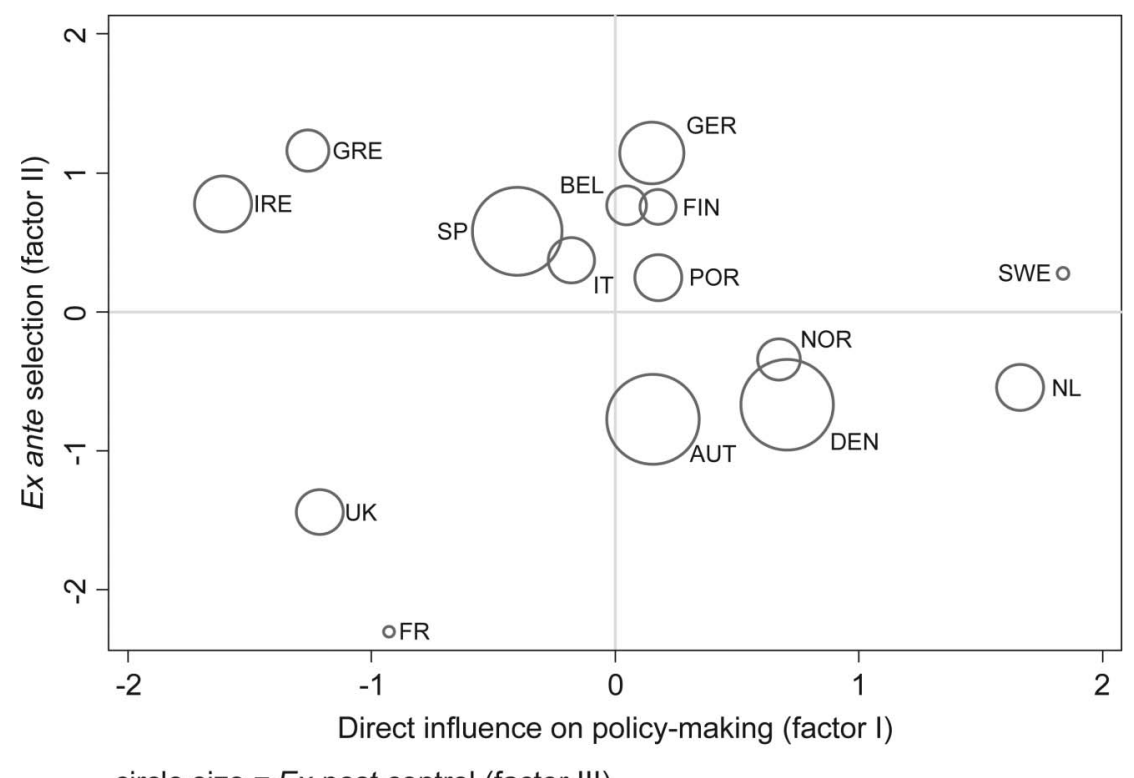

circle size $=$ Ex post control (factor III)

in a three-dimensional map based on the factor scores for the three theoretically derived factors. The numerical factor scores are reported in Table 5. The horizontal and vertical axes in Figure 1 display direct influence on policymaking and ex ante selection powers, respectively. In both cases, high values represent strong parliaments. The size of the circles indicates ex post control powers with larger circles representing higher scores. ${ }^{24}$ The grid lines mark the averages on the first two dimensions, on the third dimension only the parliaments in Denmark, Austria, Spain, Germany, and Ireland have above-average values.

Figure 1 shows that only two parliaments - the House of Commons in the UK and the French Assemblée Nationale - score below average on all three dimensions of institutional parliamentary power, whereas only the German Bundestag reaches higher-than-average values on all dimensions. The other 12 parliaments mix relative strength and weakness on different dimensions.

Let us look at some of these cases in more detail. First, the weakness of the British and French parliaments on all three dimensions requires explanation. Do these cases contradict the general argument that all parliaments have some means to influence policy outputs and mainly differ in the mechanisms used to reach this goal? The French parliament was indeed meant to be weak, as constitutional designers blamed a very powerful 
TABLE 5

THE INSTITUTIONAL POWERS OF 15 WESTERN EUROPEAN PARLIAMENTS

\begin{tabular}{lcccc}
\hline & $\begin{array}{c}\text { Factor I } \\
\text { (direct policy } \\
\text { influence) }\end{array}$ & $\begin{array}{c}\text { Factor II } \\
\text { (ex ante } \\
\text { selection) }\end{array}$ & $\begin{array}{c}\text { Factor III } \\
\text { (ex post } \\
\text { control) }\end{array}$ & $\begin{array}{c}\text { Factor IV } \\
\text { (committee } \\
\text { power) }\end{array}$ \\
\hline Austria & 0.155 & 0.776 & 1.834 & 1.433 \\
Belgium & 0.048 & 0.767 & 0.558 & 1.222 \\
Denmark & 0.707 & 0.670 & 1.892 & 1.207 \\
Finland & 0.176 & 0.756 & 0.662 & 1.068 \\
France & 0.928 & 2.300 & 1.061 & 0.862 \\
Germany & 0.150 & 1.141 & 0.300 & 0.231 \\
Greece & 1.262 & 1.162 & 0.503 & 0.434 \\
Ireland & 1.610 & 0.778 & 0.021 & 1.514 \\
Italy & 0.179 & 0.372 & 0.364 & 0.798 \\
Netherlands & 1.664 & 0.545 & 0.337 & 1.464 \\
Norway & 0.671 & 0.345 & 0.492 & 0.261 \\
Portugal & 0.177 & 0.247 & 0.345 & 0.633 \\
Spain & 0.400 & 0.578 & 1.686 & 0.780 \\
Sweden & 1.840 & 0.278 & 1.052 & 0.299 \\
United Kingdom & 1.212 & 1.441 & 0.360 & 0.717 \\
\hline
\end{tabular}

Note: Factor scores based on the rotated factors of the factor analysis reported in Table 4.

parliament for the demise of the Fourth Republic and specifically opted for a system of 'rationalised parliamentarism' (Huber 1996). ${ }^{25}$ In the British case, on the other hand, the institutional powers of parliament may be less critical because cabinets almost always consist of a single majority party. The UK relies almost exclusively on the power, of parties to align preferences across institutional arenas to avoid agency loss in a system featuring extensive delegation to the cabinet with only basic institutional checks such as the no-confidence procedure (Cox 1987).

Second, parliaments with very high scores on the first factor are rather weak with regard to ex ante selection and ex post control, indicating that there is a substitution effect for parliaments with very strong legislative powers. ${ }^{26}$ Two of the four parliaments with the highest scores on this factor (Norway and the Netherlands) are below average on the other two factors, and Sweden combines very weak ex post control with only slightly higherthan-average electoral powers. Only Denmark deviates from this pattern by scoring highest of all cases on the ex post control dimension. This deviation might be attributed to the fact that Danish minority cabinets were quite frequently confronted with an 'alternative majority' in parliament (Damgaard 1994) that had strong incentives for ex post control.

Third, many parliaments considered weak based on their lawmaking powers are strong with regard to the other dimensions. For example, the Greek and Irish parliaments have strong electoral powers which could offset some of their weakness with regard to lawmaking. Both parliaments are directly involved in choosing the cabinet and various external officeholders (the president and the ombudsman in the Greek case, the head of the audit 
institution and the ombudsman in Ireland). Similarly, the classification of the Spanish parliament as weak overlooks its strong powers in the selection of external officeholders (constitutional judges, auditors, and the ombudsman) and especially in the ex post control of the cabinet. These deviations from conventional wisdom clearly indicate that an exclusive focus on lawmaking as a source of parliamentary power leads to biased assessments and must be complemented by a systematic analysis of powers with regard to the ex ante selection of officeholders and the ex post control of the cabinet.

\section{Conclusion}

Parliaments are more than lawmaking bodies. Scholars have long realised this simple fact and discussed a number of parliamentary functions beyond legislating. However, parliamentary activities other than lawmaking and cabinet formation as well as the relationship of parliamentary powers with regard to different functions have received little theoretical and empirical attention. I addressed and narrowed this gap in three ways. First, I argued theoretically that parliamentary powers with regard to traditional functions of parliaments can be understood as different institutional mechanisms for reaching the common goal of policy outputs in line with the collective preferences of parliament. Relying on the principal-agent framework, I identified direct influence on policymaking, ex ante selection of external officeholders, and ex post control of the cabinet as three distinct dimensions of parliamentary power. Second I developed a new set of indicators to measure electoral competencies of parliaments as an empirically largely neglected facet of parliamentary powers. Third, the paper provides the first systematic analysis of the dimensionality of the institutional powers of 15 Western European parliaments and shows that the theoretically derived mechanisms correspond to independent empirical dimensions. Qualitative data from case studies indicate that direct influence on policymaking and electoral powers are independent in Eastern member states of the EU as well suggesting that my findings are valid beyond the sample analysed here (Sieberer 2008). Overall, the results of this paper show that the conventional focus on lawmaking misses theoretically and empirically relevant and independent institutional resources of parliaments and thus leads to a biased assessment of parliamentary strength and weakness.

These findings point to three interesting avenues for future research. First, this paper identified patterns and differences in institutional powers but did not analyse behaviour and outputs. From the perspective of rational choice institutionalism, institutional variables interact with actor preferences to affect behaviour and produce outputs. Thus, an extension of the research started here should focus on the effects of institutions as well as actor constellations on parliamentary behaviour. Such research could help identify the direct and indirect impact of various parliamentary actors on specific policy decisions and thus substantiate the claim that different 
institutional powers provide actors with actual and not only potential influence.

Second and related, the distinction of three mechanisms through which parliaments can influence policy outputs raises the question of their relative success. Are parliaments more successful in avoiding agency loss if they have strong powers in the legislative process, or can electoral powers and/or control capacities ultimately lead to equally good or even better results? This question is central for a PA-based assessment of the role of parliaments. Its systematic analysis requires output-based measures of agency loss which are not currently available. Developing such measures, however, would be a very useful project for comparative legislative studies rooted in the principal-agent framework.

Third, the observed multidimensionality of parliamentary powers begs the question of its genesis. Can we identify specific actor decisions leading to the observed patterns of institutional strength and weakness? And how can we explain the different priorities in different parliaments? The creation and development of parliamentary institutions has been analysed convincingly in single countries (e.g. Cox 1987 on the UK, Huber 1996 on France). However, we lack truly comparative studies of the design of parliamentary institutions (for a first step in this direction see Sieberer et al. 2011). Such analyses could both increase our understanding of institutional design processes in general and shed light on a thus far under-researched aspect of conflict over the institutional parameters of party competition in parliamentary democracies.

\section{Acknowledgements}

I gratefully acknowledge very helpful comments and suggestions by John Carey, Steffen Ganghof, Marcelo Jenny, André Kaiser, Richard S. Katz, Bernhard Miller, Wolfgang C. Müller, and two anonymous reviewers.

\section{Notes}

1. The name is somewhat misleading because the British cabinet assumes office without a formal investiture vote in parliament.

2. Only the general importance of different functions and the question of whether control and recruitment became more important compared to lawmaking in general was discussed in the context of the decline of parliaments thesis (Bryce 1921; Loewenberg 1971).

3. As stated above, political parties play an essential role in aligning actor preferences across institutional arenas. A high level of party unity decreases the impact of institutional powers of parliamentary actors vis à vis the cabinet. Thus, the institutional powers covered in this paper present the maximal potential for parliamentary power but are not fully applied under all circumstances.

4. My argument does not touch on functions like representation, legitimisation and providing a forum for public debate that cannot be conceptualised as institutional powers. In addition, some functions discussed in the literature, e.g. Packenham's (1990 [1970]) 'recruitment, socialisation, and training functions', entail elements beyond the institutional powers covered here. 
5. These countries are: Austria, Belgium, Denmark, Finland, France, Germany, Greece, Ireland, Italy, the Netherlands, Norway, Portugal, Spain, Sweden, and the United Kingdom. I treat France as a parliamentary democracy because it satisfies the most important defining characteristic that the cabinet can be forced to resign by a majority vote in parliament (Muller et al. 2003). Extending the analysis to the settler democracies or Eastern Europe would require massive data collection and was not feasible in the context of this project even though it offers a valuable perspective for future research.

6. Italy is an extraordinary case in this respect because the cabinet is accountable to both the Chamber of Deputies and the Senate. Due to data problems, my analysis covers only the Chamber of Deputies. Furthermore, the focus on lower chambers might be problematic in countries such as Australia where the second chamber is specifically designed to control the cabinet and the majority in the first chamber. However, none of the cases covered in this paper follows such a pattern.

7. Budgetary powers are sometimes considered a separate function from lawmaking. I treat them as a subcategory of lawmaking powers in line with Bagehot's original formulation.

8. As these measures are taken from existing studies, they refer to different points in time ranging from the mid 1990s to today. Unfortunately, time specific data is not available. Thus we can neither measure them all at the same point in time nor capture institutional change in parliaments. However, the basic institutional parameters of parliamentary competition covered here tend to be rather stable over time in most countries. Thus the lack of time sensitive measures should not lead to massive distortions in the empirical analysis.

9. No confidence procedures do differ in details, especially the question of whether a cabinet has to be replaced by an alternative in a constructive vote of no confidence and of whether no confidence votes can be directed against individual ministers. For more information on these differences and their relationship to electoral powers with regard to the cabinet see Sieberer (2010: Ch. 5).

10. If a member of a collective body is elected, the relevant status quo is the ideal point of the median of the remaining members as he or she dominates decision making if the vacancy was to prevail (Krehbiel 2007). If parliament elects a single officeholder, we can treat the incumbent's ideal point as status quo because he or she often remains in office until a successor is elected or procedures established by the incumbent are carried out by administrative staff.

11. I subsume political parties as organisations under parliamentary actors because parliamentary party groups often play an important role within party organisations (Heidar and Koole 2000). Distinctions within the group of cabinet actors between the prime minister, a specific minister, or cabinet as a collective body are not pursued here, even though they could be relevant in coalitions or highly factionalised one party cabinets.

12. An index based on the alternative ordering of the two dimensions (AM3 $<$ AM $2<\mathrm{AM} 1<$ CEM $3<$ CEM $2<$ CEM1) is highly correlated with the one I use in the cases analysed

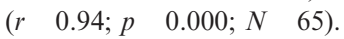

13. These values give the three variables (number of candidates, nominating actor, and majority requirement) approximately equal impact on the rank ordering of the index scores. Coding the majority requirement as $1 ; 2 ; 3$ leads to very similar results $(r \quad 0.98 ; p \quad 0.000$; $\begin{array}{ll}N & 65) \text {. }\end{array}$

14. Using an additive link instead leads to very similar results $\left(\begin{array}{llll}r & 0.93 ; p & 0.000 ; N & 65\end{array}\right)$.

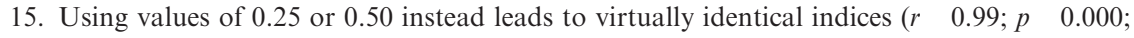

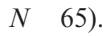

16. Some of these external officeholders are not agents in the strict sense as they are not accountable to parliament after assuming office. Nonetheless, parliamentary actors can affect their preferences and thus expected behaviour via the election. Therefore, they can use electoral powers as means to indirectly affect policy outputs and reduce agency loss.

17. In some countries the number of offices is lower because there is no constitutional court (e.g. in the UK and the Netherlands) or ombudsman (in Germany and Italy). 
18. I use the number of existing offices because not electing a non existent officeholder does not indicate a weak parliament.

19. The unweighted index is highly correlated with an index assigning double weight to the election of the prime minister and cabinet $(r \quad 0.97$ for PFCI and $r \quad 0.98$ for ICI; $p \quad 0.000$; $N \quad 15$ ) and an index weighing the prime minister and cabinet by a factor of three, heads of states and constitutional judges by two and heads of audit institutions and ombudsmen by one $\left(\begin{array}{llll}r & 0.90 \text { for PFCI and } r \quad 0.94 \text { for ICI; } p \quad 0.000 ; N & 15\end{array}\right)$.

20. The principal factors method does not assume that the factors completely capture the variance in the variables which seems appropriate given the sometimes rough measurement of the theoretical concepts. Using principal component factors instead leads to very similar results. The varimax rotation ensures statistical independence of the factors and facilitates their interpretation. The estimation was performed in STATA 10. The use of factor analysis is methodologically problematic for some variables with few values because the assumption of a multivariate normal distribution is violated. Despite this problem, scholars frequently apply factor analytic procedures to this kind of data (Mattson and Strøm 1995; Tsebelis 2002). I follow this established procedure.

21. The confidence intervals are estimated using the bias corrected and accelerated method because the simulation indicates bias in the eigenvalues.

22. The percentage of variance captured by a factor does not constitute a measure of its substantial importance because it depends both on the choice of input variables (the more variables relate to a factor the higher its explained variance) and on the rotation procedure.

23. Two variables have loadings higher than 0.5 on a second factor in addition to the one they belong to theoretically. The control structures index correlates with factor I. A plausible explanation is that the index includes elements that are relevant for both control and lawmaking (e.g. the size and jurisdictions of committees). Committee powers to rewrite government bills also load on factor II. I have no theoretical explanation for this result. Note, however, that the variable is also correlated with factor I and retains a relevant uniqueness value which indicates a weak overall fit with the factor solution.

24. A value of 1.10 was added to the scores for the third factor because the size of the circles must be positive. This linear transformation does not affect the ordering of the countries.

25. However, the strong institutional prerogatives of the cabinet in the legislative process do not keep parliament from amending bills quite frequently (Brouard 2011) which reinforces the point that we cannot infer behaviour directly from institutional rules.

26. By necessity, the factors are uncorrelated across all cases because of the varimax rotation.

\section{References}

Bagehot, Walter (1963 [1867]). The English Constitution. London: Oxford University Press.

Bergman, Torbjorn (1993). 'Formation Rules and Minority Governments', European Journal of Political Research, 23:1, 5566.

Black, Duncan (1987 [1958]). The Theory of Committees and Elections. Boston, MA: Kluwer. Blondel, Jean (1973). Comparative Legislatures. Eaglewood Cliffs, NJ: Prentice Hall.

Braun, Dietmar, and Fabrizio Gilardi, eds. (2006). Delegation in Contemporary Democracies. London: Routledge.

Brouard, Sylvain (2011). 'France: Systematic Institutional Advantage of Government in Law Making', in Bjorn Erik Rasch and George Tsebelis (eds.), The Role of Governments in Legislative Agenda Setting. London: Routledge, 3852.

Bryce, James (1921). Modern Democracies. New York: Macmillan.

Carey, John M. (2007). 'Competing Principals, Political Institutions, and Party Unity in Legislative Voting', American Journal of Political Science, 51:1, 92107.

Carroll, Royce, Gary W. Cox, and Mónica Pachón (2006). 'How Parties Create Electoral Democracy, Chapter 2', Legislative Studies Quarterly, 31:2, 15374. 
Cox, Gary W. (1987). The Efficient Secret. The Cabinet and the Development of Political Parties in Victorian England. Cambridge: Cambridge University Press.

Damgaard, Eric (1994). 'Denmark. Experiments in Parliamentary Government', in Eric Damgaard (ed.), Parliamentary Change in the Nordic Countries. Oslo: Scandinavian University Press, 1849.

Doring, Herbert, ed. (1995a). Parliaments and Majority Rule in Western Europe. Frankfurt: Campus.

Doring, Herbert (1995b). 'Time as a Scarce Resource: Government Control of the Agenda', in Herbert Doring (ed.), Parliaments and Majority Rule in Western Europe. Frankfurt: Campus, 223246.

Dowding, Keith (1996). Power. Buckingham: Open University Press.

Downs, Anthony (1957). An Economic Theory of Democracy. New York: Harper \& Row.

Epstein, David, and Sharyn O'Halloran (1999). Delegating Powers. A Transaction Cost Politics Approach to Policy Making under Separate Powers. Cambridge: Cambridge University Press.

Gallagher, Michael, Michael Laver, and Peter Mair (2006). Representative Government in Modern Europe. 4th ed. Boston, MA: McGraw Hill.

Gamm, Gerald, and John Huber (2002). 'Legislatures as Political Institutions: Beyond the Contemporary Congress', in Ira Katznelson and Helen V. Milner (eds.), Political Science. The State of the Discipline. New York: W.W. Norton, 31341.

Heidar, Knut, and Ruud Koole, eds. (2000). Parliamentary Party Groups in European Democracies: Political Parties Behind Closed Doors. London: Routledge.

Huber, John D. (1996). Rationalizing Parliament. Legislative Institutions and Party Politics in France. Cambridge: Cambridge University Press.

Jenny, Marcelo, and Wolfgang C. Muller (1995). 'Presidents of Parliaments. Neutral Chairmen or Assets of the Majority?', in Herbert Doring (ed.), Parliaments and Majority Rule in Western Europe. Frankfurt: Campus, 32664.

Kiewiet, Roderick D, and Mathew D. McCubbins (1991). The Logic of Delegation. Congressional Parties and the Appropriations Process. Chicago: University of Chicago Press.

Kim, Dong Hun, and Gerhard Loewenberg (2005). 'The Role of Parliamentary Committees in Coalition Governments. Keeping Tabs on Coalition Partners in the German Bundestag', Comparative Political Studies, 38:9, 110429.

King, Anthony (1976). 'Modes of Executive Legislative Relations: Great Britain, France, and West Germany', Legislative Studies Quarterly, 1:1, 1134.

King, Gary, James E. Alt, Nancy Elizabeth Burns, and Michael Laver (1990). 'A Unified Model of Cabinet Dissolution in Parliamentary Democracies', American Journal of Political Science, $34: 3,84671$.

Krehbiel, Keith (2007). 'Supreme Court Appointments as a Move the Median Game', American Journal of Political Science, 51:2, 23140.

Laver, Michael (2006). 'Legislatures and Parliaments in Comparative Context', in Barry Weingast and Donald Wittman (eds.), The Oxford Handbook of Political Economy. Oxford: Oxford University Press, 12140.

Loewenberg, Gerhard, ed. (1971). Parliaments. Change or Decline? Chicago: Aldine Atherton.

Loewenberg, Gerhard, and Samuel C. Patterson (1979). Comparing Legislatures. Boston, MA: Little, Brown and Company.

Martin, Lanny W., and Georg Vanberg (2004). 'Policing the Bargain. Coalition Government and Parliamentary Scrutiny', American Journal of Political Science, 48:1, 1327.

Mattson, Ingvar, and Kaare Strøm (1995). 'Parliamentary Committees', in Herbert Doring (ed.), Parliaments and Majority Rule in Western Europe. Frankfurt: Campus, 249307.

McCubbins, Mathew D., and Thomas Schwartz (1984). 'Congressional Oversight Overlooked. Police Patrol versus Fire Alarms', American Journal of Political Science, 28:1, 16597.

Mezey, Michael L. (1979). Comparative Legislatures. Durham, NC: Duke University Press. 
Muller, Wolfgang C. (2000). 'Political Parties in Parliamentary Democracies. Making Delegation and Accountability Work', European Journal of Political Research, 34:3, 30933.

Muller, Wolfgang C., Torbjorn Bergman, and Kaare Strøm (2003). 'Parliamentary Democracy. Promise and Problems', in Kaare Strøm, Wolfgang C. Muller, and Torbjorn Bergman (eds.), Delegation and Accountability in Parliamentary Democracies. Oxford: Oxford University Press, 332.

Norton, Philip, ed. (1990). Parliaments in Western Europe. London: Frank Cass.

Norton, Philip, ed. (1998). Parliaments and Governments in Western Europe. London: Frank Cass.

Packenham, Robert A. (1990 [1970]). 'Legislatures and Political Development', in Philip Norton (ed.), Legislatures. Oxford: Oxford University Press, 8196.

Polsby, Nelson W. (1975). 'Legislatures', in Fred I. Greenstein and Nelson W. Polsby (eds.), Handbook of Political Science. Vol. 5. Reading, MA: Addison Wesley, 257319.

Rasch, Bjorn Erik, and George Tsebelis, eds. (2011). The Role of Governments in Legislative Agenda Setting. London: Routledge.

Romer, Thomas, and Howard Rosenthal (1978). 'Political Resource Allocation, Controlled Agendas, and the Status Quo', Public Choice, 33:4, 2744.

Saalfeld, Thomas (1995). 'On Dogs and Whips. Recorded Votes', in Herbert Doring (ed.), Parliaments and Majority Rule in Western Europe. Frankfurt: Campus, 52865.

Saalfeld, Thomas (2008). 'Institutions, Chance and Choices. The Dynamics of Cabinet Survival in the Parliamentary Democracies of Western Europe (1945 1999)', in Kaare Strøm, Wolfgang C. Muller, and Torbjorn Bergman (eds.), Cabinets and Coalition Bargaining. The Democratic Life Cycle in Western Europe. Oxford: Oxford University Press, 32768.

Schnapp, Kai Uwe, and Philipp Harfst (2005). 'Parlamentarische Informations und Kontrollres sourcen in 22 westlichen Demokratien', Zeitschrift für Parlamentsfragen, 36:2, 34870.

Shepsle, Kenneth A. (1979). 'Institutional Arrangements and Equilibrium in Multidimensional Voting Models', American Journal of Political Science, 23:1, 2759.

Sieberer, Ulrich (2006a). 'Party Unity in Parliamentary Democracies. A Comparative Analysis', Journal of Legislative Studies, 12:2, 15078.

Sieberer, Ulrich (2006b). 'Agenda Setting in the German Bundestag. A Weak Government in a Consensus Democracy', German Politics, 15:1, 4972.

Sieberer, Ulrich (2008). 'Prinzipal Parlament. Die Bedeutung europaischer Parlamente als Wahlorgane', Politische Vierteljahresschrift, 49:2, 25182.

Sieberer, Ulrich (2010). Parlamente als Wahlorgane. Parlamentarische Wahlbefugnisse und ihre Nutzung in 25 europäischen Demokratien. Baden Baden: Nomos.

Sieberer, Ulrich, Wolfgang C. Muller, and Maiko Isabelle Heller (2011). 'Reforming the Rules of the Parliamentary Game: Measuring and Explaining Changes in Parliamentary Rules in Austria, Germany, and Switzerland, 1945 2010', West European Politics, 34:5, forthcoming.

Strøm, Kaare (1990). Minority Government and Majority Rule. Cambridge: Cambridge University Press.

Strøm, Kaare (2000). 'Delegation and Accountability in Parliamentary Democracies', European Journal of Political Research, 37:3, 26189.

Strøm, Kaare (2003). 'Parliamentary Democracy and Delegation', in Kaare Strøm, Wolfgang C. Muller, and Torbjorn Bergman (eds.), Delegation and Accountability in Parliamentary Democracies. Oxford: Oxford University Press, 55106.

Strøm, Kaare, Wolfgang C. Muller, and Torbjorn Bergman, eds. (2003). Delegation and Accountability in Parliamentary Democracies. Oxford: Oxford University Press.

Thatcher, Mark, and Alec Stone Sweet, eds. (2002). The Politics of Delegation: Non Majoritarian Institutions in Europe. Special Issue of West European Politics, 25:1.

Tsebelis, George (2002). Veto Players. How Political Institutions Work. Princeton, NJ: Princeton University Press.

Wehner, Joachim (2006). 'Assessing the Power of the Purse. An Index of Legislative Budget Institutions', Political Studies, 54:4, 76785.

Wiberg, Matti (1995). 'Parliamentary Questioning. Control by Communication?', in Herbert Doring (ed.), Parliaments and Majority Rule in Western Europe. Frankfurt: Campus, 179 222 . 


\section{APPENDIX \\ OPERATIONALISATION OF THE INDICATORS OF INSTITUTIONAL PARLIAMENTARY POWERS}

\begin{tabular}{|c|c|}
\hline Variable & Operationalisation [Extreme values for categorical variables] \\
\hline Determine plenary agenda & $\begin{array}{l}\text { Rights of the government in determining the plenary agenda. } \\
{[1=\text { The government alone determines the plenary agenda; } 7=\text { The chamber }} \\
\text { itself determines the agenda }]\end{array}$ \\
\hline $\begin{array}{l}\text { Control committee } \\
\text { timetable }\end{array}$ & $\begin{array}{l}\text { Rights of committees to control their own agenda. } \\
{[1=\text { Bills tabled before the committee automatically constitute the agenda; }} \\
4=\text { House may not reallocate bills to other committees }]\end{array}$ \\
\hline Curtailing of debate & $\begin{array}{l}\text { Rules for ending debate before the final vote on a bill in the plenary. } \\
{[1=\text { Limitation in advance by majority rule; } 3=\text { Neither advance limitation }} \\
\text { nor cloture }]\end{array}$ \\
\hline $\begin{array}{l}\text { Committees: Rewrite } \\
\text { government bills }\end{array}$ & $\begin{array}{l}\text { Authority of committees to rewrite government bills. } \\
\text { [1= House considers original government bill with amendments added; } \\
4=\text { Committees are free to rewrite government text }]\end{array}$ \\
\hline $\begin{array}{l}\text { Committees: Initiation of } \\
\text { bills }\end{array}$ & $\begin{array}{l}\text { Right of legislative committees to initiate legislation. } \\
{[1=\text { free right to initiate; } 3=\text { no right to initiate, consolidate, or split bills }]}\end{array}$ \\
\hline $\begin{array}{l}\text { Legislative budget } \\
\text { institutions }\end{array}$ & $\begin{array}{l}\text { Index based on data of the Survey on Budget Practices and Procedures } \\
\text { conducted by OECD and World Bank in 2003. The index is calculated } \\
\text { from six variables on (1) legislative powers to amend the budget bill, (2) } \\
\text { the consequences if the budget is not approved at the start of the fiscal } \\
\text { year, (3) the flexibility of the government in implementing the budget law, } \\
\text { (4) the amount of time parliament has to work on the budget bill, (5) the } \\
\text { role of committees in approving the budget, and (6) the level of legislative } \\
\text { budget research capacity. The first three and last three variables are added } \\
\text { and the resulting partial indices multiplied. Afterwards, the index is } \\
\text { rescaled to the range from } 0 \text { to } 100 \text {. }\end{array}$ \\
\hline $\begin{array}{l}\text { Committees: Compel } \\
\text { witnesses }\end{array}$ & $\begin{array}{l}\text { Right of committees to compel witnesses to testify. } \\
{[0=\text { cannot compel; } 1=\text { can compel }]}\end{array}$ \\
\hline $\begin{array}{l}\text { Committees: Demand } \\
\text { documents }\end{array}$ & $\begin{array}{l}\text { Right of committees to demand documents from the government. } \\
{[0=\text { cannot demand; } 1=\text { can demand }]}\end{array}$ \\
\hline Parliamentary questions & $\begin{array}{l}\text { Additive index giving one point for each of the following types of questions } \\
\text { existing in a parliament: (1) written question, (2) oral question, (3) urgent } \\
\text { question, (4) topical hour, (5) committee question, (6) interpellation with } \\
\text { motion of censure, (7) interpellation without motion of censure, ( } 8) \\
\text { question to government, and (9) budgetary question. The data on } \\
\text { question types are taken from Wiberg (1995). }\end{array}$ \\
\hline Control structures & $\begin{array}{l}\text { Index based on a survey of presidents of parliament and institutional data on } \\
\text { (1) the number of committees, (2) the size of committees, (3) the } \\
\text { correspondence of committees with government departments, and (4) } \\
\text { average number of committee assignment per deputy. The index is } \\
\text { constructed as the average values of a parliament's ranks on the } \\
\text { individual indicators. I reversed the sign of the index values so that high } \\
\text { values signal strong parliaments. }\end{array}$ \\
\hline Control rights & $\begin{array}{l}\text { Index based on a survey of presidents of parliament and institutional data on } \\
\text { (1) powers of committees to obtain information, (2) the time parliament } \\
\text { has to work on government bills in the budget process, and (3) the } \\
\text { existence of independent audit institutions and ombudsmen. The index is } \\
\text { constructed as the average values of a parliament's ranks on the } \\
\text { individual indicators. I reversed the sign of the index values so that high } \\
\text { values signal strong parliaments. }\end{array}$ \\
\hline Positive parliamentarism & $\begin{array}{l}\text { Does the prime minister and/or the cabinet have to win an investiture vote } \\
\text { with at least a relative majority prior to or right after assuming office? } \\
{[0=\text { no; } 1=\text { yes }]}\end{array}$ \\
\hline $\begin{array}{l}\text { Parliamentary freedom of } \\
\text { choice }\end{array}$ & See main text. \\
\hline Incentives to constrain & See main text. \\
\hline
\end{tabular}

